\title{
Prognostic Determinants in Prostate Cancer
}

\author{
Neil E Martin, MD ${ }^{1}$, Lorelei A Mucci, ScD², Massimo Loda, MD ${ }^{3}$, and Ronald A DePinho, \\ $\mathrm{MD}^{4}$ \\ ${ }^{1}$ Instructor, Department of Radiation Oncology, Brigham and Women's Hospital/Dana-Farber \\ Cancer Institute, Boston, MA \\ ${ }^{2}$ Associate Professor, Department of Epidemiology, Harvard School of Public Health, Boston, MA \\ ${ }^{3}$ Professor, Department of Pathology, Brigham and Women's Hospital/Dana-Farber Cancer \\ Institute, Boston, MA \\ ${ }^{4}$ Professor, Department of Cancer Biology, UT MD Anderson Cancer Center, Houston, TX
}

\begin{abstract}
Clinical outcomes in prostate cancer are heterogeneous and given the high prevalence of the disease, there is a pressing need to identify clinically useful markers of prognosis. Many clinical, pathologic, molecular, and genetic factors have been investigated in this capacity though relatively few are routinely used. With a growing understanding of the molecular pathogenesis of prostate cancer, there is the potential that the next generation of makers will prove sufficiently robust to guide the optimal management of men with prostate cancer. Here, we review the various clinical and molecular prognostic determinants in prostate cancer.
\end{abstract}

\section{Keywords}

prognosis; prostate; gene expression signatures; immunohistochemistry

\section{Introduction}

Prostate cancer is a major cause of morbidity and mortality among men in the United States and globally. However, many men with prostate cancer have a slow growing tumor and experience an indolent course even without curative therapy ${ }^{1}$. The Scandinavian trial of radical prostatectomy versus watchful waiting 2,3 demonstrated that surgery decreases subsequent risk of metastases and prostate cancer death. However, 15 men had to be treated to prevent one cancer-specific death during a median 12 years of follow-up. Conversely, some men with apparently localized disease die of their cancer despite initial therapy because of the presence of undiagnosed micrometastases.

The biologic heterogeneity in prostate cancer has been brought into sharp focus as a result of widespread adoption of prostate specific antigen (PSA) screening in many countries, with a resulting marked migration towards the diagnosis of lower-risk prostate cancer ${ }^{4}$. There are now more than 240,000 men in the United States diagnosed with prostate cancer each year ${ }^{5}$, and 90 percent of prostate cancers are clinically localized and occult disease at time of diagnosis ${ }^{4}$. Data from the randomized trials of PSA screening ${ }^{6-8}$ highlight the considerable over diagnosis and overtreatment of men with screen-detected prostate cancer with very low prostate-cancer specific mortality rates in modern series ${ }^{9}$. 
The high incidence of prostate cancer in Western countries underscores the urgency to develop means to distinguish indolent from potentially lethal prostate cancer and accurately identify at the time of diagnosis men for whom treatment is indicated. Traditionally, clinical factors have been used to risk stratify prostate cancer patients and provide guidance around the risk of cancer progression and need for treatment. In the era before PSA screening, these clinical factors provided good, but not perfect, prognostic information. However, the advent of PSA screening has led to a loss in the discriminatory power of these clinical and pathologic features ${ }^{10}$. Thus, research has turned to the identification of molecular drivers of prostate cancer, in tumors and circulation, that could be integrated with clinical factors and improve prognostication. The search for molecular prognostic determinants is particularly challenging in prostate cancer given the enormous intratumoral genomic and biological heterogeneity in most early stage prostate cancers. While clinical validation of markers remains limited, several recent additions to the field show great promise.

In this review, we present an overview of evidence on prognostic features in prostate cancer. We discuss clinical and pathological features, as well as molecular markers in tumors and circulation. We also consider some of the major methodologic challenges in the identification of prognostic determinants in prostate cancer.

\section{Clinical Factors}

Several clinical and pathological features at the time of diagnosis or surgery have been investigated as potential prognostic factors in prostate cancer. The established tumor-related factors include elevated prostate specific antigen (PSA) level at diagnosis, more advanced clinical and pathological tumor stage, higher Gleason score ${ }^{10}$ and positive tumor margins ${ }^{9,11}$. Kattanet al $^{12}$ and others ${ }^{13,14}$ have developed useful nomograms with these parameters to predict biochemical recurrence after prostatectomy. Because of the long clinical course of prostate cancer, especially with the five to ten year lead-time added by PSA screening ${ }^{15}$, most studies have used a rise in the PSA following local therapy (biochemical recurrence), to assess risk of disease progression. This is however, an imperfect surrogate for prostate cancer mortality, as the vast majority of these men are not destined to die of their disease ${ }^{16-18}$.

\section{Gleason grade}

Gleason score is the strongest clinical predictor of prostate cancer progression ${ }^{19}$. The grading system, first described in the 1960s, characterizes prostate tumor architecture and morphology. The pathologist assigns a primary and secondary score, and the total score is summed with a range of 2 to 10 . Men diagnosed with Gleason grade 7 or higher tumors are at increased risk of extraprostatic extension, increased risk of recurrence after initial therapy, and more likely to die of their disease. In contrast, men diagnosed with well-differentiated Gleason 6 disease are at very low risk of cancer-specific death. In a multi-institutional radical prostatectomy cohort, the 15 -year prostate cancer-specific mortality rates varied by the age of the patients at diagnosis ranging from $0.2-1 \%$ percent for pathological Gleason 6 or less, $4-6$ percent for Gleason 3+4 tumors, $6-11$ percent for Gleason $4+3$ tumors, and $26-37$ percent for Gleason 8 or higher cancers ${ }^{20}$.

The distribution of Gleason grades has shifted over time ${ }^{21}$, and in the era of PSA screening, most men are now diagnosed with Gleason 6 or 7 tumors. As such, the accurate discrimination of prognosis among men with prostate cancer within this narrow range of Gleason scores is challenging. Some ${ }^{22}$, but not all ${ }^{23}$, studies suggest that there is prognostic information among Gleason 7 tumors on whether the predominant pattern is Gleason 4 or 3 . For example, in a population-based radical prostatectomy series, men with pathological Gleason $4+3$ tumors had a 3 -fold greater risk of prostate cancer-specific mortality compared 
to men with Gleason $3+4$ tumors $^{22}$. Still, prognostication among Gleason 7 prostate cancer is far from accurate.

An important consideration in evaluating the prognostic value of Gleason has been the noted shift in Gleason grading over time, which has resulted in a general increase in scores with more contemporary reads and almost no men diagnosed with Gleason $<6$ tumors ${ }^{21,24}$. Moreover, there is considerable inter-rater variability in assigning Gleason grades across institutions. A comparison of standardized reviews to original Gleason score reviews demonstrates that the systematic upgrading in Gleason results in improved survival for all Gleason categories ${ }^{22}$.

\section{Prostate Specific Antigen}

Both the level of PSA and the velocity of rise prior to diagnosis have been explored as potential risk factors for poor outcome following definitive treatment. Level of PSA at diagnosis is a component of the standard risk stratification factors ${ }^{10}$ and remains a component of most clinical nomograms ${ }^{11,25}$. With the majority of men diagnosed today through PSA screening, the typical PSA level at diagnosis has decreased ${ }^{4}$, reducing the sensitivity of this measure. A rapidly rising PSA prior to diagnosis has been identified as a strong predictor for poor outcome following surgery ${ }^{26}$ or radiation ${ }^{27}$ though other large studies have not found this relationship among men diagnosed during the PSA-era9 ${ }^{9}$.

\section{Perineural Invasion}

The presence of cancer cells invading the space around nerves has been found to be of prognostic relevance in other malignancies and is thought to be a mechanism by which prostate cancer can extend beyond the capsule ${ }^{28}$. Numerous studies have investigated the prognostic role of perineural invasion seen on biopsy on outcome following radical local treatment ${ }^{29,30}$. Observed in between 10 and 40 percent of cases, the significance of perineural invasion for recurrence has been mixed across studies though ultimately appears to be associated with a worsened prognosis ${ }^{31}$. When identified on prostatectomy specimen, this factor has typically not been associated with a worsened outcome ${ }^{32}$.

\section{Clinical risk groups and nomograms}

Beyond individual factors, the combination of clinical and pathological factors represents a more powerful tool to aid in prostate cancer prognostication. When combined together, the predictive power of the clinical and pathological features has consistently been shown to be greater than any single factor. There are multiple published studies that have developed tools in this regard, including the development of simple risk categories, risk calculators as well as clinical nomograms. The predictive utility of these combined clinical sets to risk stratify prostate cancer patients have been evaluated primarily in cohorts of patients following curative therapy, either radiation or prostatectomy. Moreover, most have relied on surrogate disease endpoints of PSA recurrence or biochemical failure. We present below examples of each type of categorization of features that are used clinically in a variety of settings.

Risk categories-Risk categories provide clinicians and patients a qualitative assessment of the likelihood of prostate cancer progression after initial therapy. One example of risk categorization is the D'Amico Risk Classification that divides men into low risk, intermediate risk and high-risk categories of progression after radical prostatectomy, based on clinical stage, biopsy Gleason grade, and preoperative levels of PSA ${ }^{10}$. The risk grouping of an individual patient by the D'Amico classification system is determined by his most clinically advanced clinical feature, rather than a summary consideration of all three features. This risk classification system has been demonstrated in independent patient populations to provide accurate prediction of recurrence after radical prostatectomy ${ }^{33}$. 
Nomograms-Nomograms are chart-based tools using a scoring system of clinical characteristics to estimate individualized risk of recurrence and progression. The Kattan nomogram ${ }^{12}$ is one of the most widely used preoperative nomograms for the prediction of biochemical recurrence after radical prostatectomy. This nomogram uses information on clinical stage, Gleason grade on biopsy and pretreatment PSA levels to provide predicted probability of biochemical recurrence 5 years after radical prostatectomy. The nomogram was developed in a patient cohort with primarily clinically localized, low-risk disease. A recent study further tested the accuracy of the Kattan nomogram across high and low risk strata defined by the D'Amico risk classification ${ }^{34}$. In that study, the authors were able to confirm the nomograms predictive ability to estimate risk of recurrence for patients with high and low-risk prostate cancer. PSA recurrence is a good, but not perfect, predictor of development of distant metastases or cancer-specific mortality. Walz et al ${ }^{25}$ examined the endpoint of recurrence within two years after surgery, given that early recurrence may better reflect the likelihood of micrometastatic disease. This nomogram reported that men with evidence of extraprostatic cancer were much more likely to experience an early recurrence, with a relative risk of early recurrence among men with tumors that had penetrated the capsule of 1.8, and for men with seminal vesicle involvement a relative risk of 3 .

\section{Molecular Factors}

While clinical factors have proven useful for risk stratification and guidance of treatment decisions in prostate cancer, significant clinical heterogeneity remains and many molecular and genetic factors have been explored to better individualize risk prediction. The ideal marker would be measurable at diagnosis, would have both high sensitivity and specificity for distinguishing lethal and indolent prostate cancer, be cost-effective, and be reliably measured across observers and institutions ${ }^{35}$. Despite the pressing need to evaluate markers in populations undergoing surveillance, the vast majority of molecular factors have been explored in definitively treated cohorts such as those undergoing radical prostatectomy or radiation therapy. The prognostic value of these markers among potentially untreated men is an area with limited testing. Another important consideration in the evaluation of molecular factors is the selection of disease endpoints. Outcomes have typically focused on recurrence after local therapy as evidenced by a rise in PSA, a feature which does not always correlated to prostate cancer morbidity or mortality.

Notably, unlike other solid tumors, prostate cancer is not characterized by frequent mutations carrying prognostic or predictive value $e^{36,37}$. Thus, molecular factors examined to date in prostate cancer prognostication have focused on alterations in copy number, mRNA and more recently miRNA. In this review, we highlight molecular tumor features which have been explored as potential biomarkers of prognosis according to the broad hallmarks of cancer described by Hanahan and Weinberg ${ }^{38,39}$ with selected examples provided in the Table. Moreover, we discuss the identification of molecular signatures that have defined from either pathway-based or discovery-based approaches.

\section{Tumor Factors}

A variety of tumor-related markers have been investigated as potential prognostic markers in prostate cancer. Early studies were based on small series of clinical cohorts, with insufficient statistical power to detect meaningful associations. More recently protein expression of immunohistochemical biomarkers has been increasingly utilized, made possible with widespread adoption of tissue microarrays and automated image analysis software for quantification of protein expression. The use of tissue microarrays allows for the study of hundreds of cases while resulting in more uniform and efficient immunohistochemical staining with valid results. Moreover, the application of automated image analysis software 
has led to high throughput and quantitative evaluation of biomarkers with highly reproducible results.

Self-sufficiency in growth signals-Unlike normal cells, tumor cells develop the ability to promote growth in the absence of normally regulated signaling systems. There are numerous inter-related, pro-growth signaling pathways implicated in prostate cancer progression including androgen signaling, phosphoinositol 3-kinase (PI3K), epidermal growth factor receptor (EGFR), RAS, and metabolic dysregulation. Studies for each of several pathways of interest are presented in the Table as they relate to prognosis.

Insensitivity to antigrowth signals-Progression through the cell cycle in normal cells is a well-regulated process involving the interplay of numerous coordinated signaling factors. Loss of these control mechanisms provides tumor cells the opportunity for unchecked growth. In prostate cancer, disruption of several molecular features associated with cell cycle control provides prognostic information following radical prostatectomy including p16/INK4A, p21/WAF1/CIP1, p27/KIP1 (Table). As outlined below, cyclin D1 has also been shown to have prognostic value as a marker. An additional marker thought to be central to antigrowth regulation is the oncogenic transcription factor C-MYC. Increased copy number for $M Y C$ is prognostic for worsened outcome in prostate cancer. Additionally, the expression of genes related to cell cycle progression has been associated with poor outcome in a watchful waiting and prostatectomy cohort ${ }^{40}$.

Limitless replicative potential-Non-cancer cells have a finite capacity to replicate as determined by telomeres. These base-pair repeats at the ends of chromosomes shorten with each cell division resulting in genome instability when they are no longer capable of protecting the chromosomal ends ${ }^{41}$. Shortened telomere length in tumor cells has been associated with a poor prognosis though there are relatively few studies investigating this marker in prostate cancer.

Evasion of apoptosis-Cancer develops in the setting not only of increased pro-growth and decreased control signaling but also reduced cell attrition through apoptosis. This wellregulated process of cell death is mediated by a variety of factors several of which have been explored as prognostic factors in prostate cancer. A central signaling molecule for DNA damage and regulator of apoptosis is p53. The TP53 gene is commonly mutated in other cancers but less frequently in prostate cancer $^{36}$. Nuclear localization of $\mathrm{p} 53$, which connotes stabilized mutant protein, has been independently associated with poor prognosis in prostate tumors. Multiple other markers in the apoptotic pathways including BAX and BCL2 have also been explored as prognostic markers in prostate cancer showing potential utility (Table).

Sustained angiogenesis-As a result of limited diffusion capacity of oxygen and essential nutrients, tumors require the development of new blood vessels as they increase in size in a process referred to as neoangiogenesis. Blood vessels typically form in a highly regulated process but in tumors, the process can become disorganized. In prostate cancer, both increased vessel density ${ }^{42}$ and vessel morphology ${ }^{43}$ have been shown to be associated with prognostic implications. Additionally, tumor vascular endothelial growth factor (VEGF) expression has been associated with poor prognosis in those receiving both surgery and radiation as primary treatment.

Tissue invasion and metastasis-Prostate cancer specific mortality is typically the result of distant spread of the tumor. The processes controlling this capacity to invade and ultimately metastasize are not fully understood but the tumor microenvironment is thought 
to play a crucial role. Markers of cell adhesion such as E-cadherin and cytokines such a transforming growth factor beta (TGF- $\beta$ ) have prognostic significance following surgery in prostate cancer as outlined in the Table and below.

\section{Molecular signatures}

Rather than focusing on individual markers, 'molecular signatures' represent the use of multiple markers which together attempt provide prognostic markers of prostate cancer progression. Several groups have reported on molecular signatures derived from prostate tumors, although many have been based on small study populations. Moreover, few have identified robust signatures that validate across different prostate cancer cohorts. In order for a molecular signature to be useful clinically, the set of markers should be predictive of prostate cancer outcomes independent of Gleason grade and other clinical markers. Below we summarize the results from three promising signatures of prostate cancer recurrence and/ or death.

Molecular signature of copy number alterations-Taylor et al ${ }^{44}$ undertook an integrative genomic analysis of the tumors of 218 prostate cancer patients followed a median of 5 years for biochemical recurrence. The tumors were annotated molecularly using whole genome mRNA, miRNA and copy number aberrations platforms. Using an unsupervised hierarchical clustering, the authors were unable to identify a signature at the mRNA nor miRNA levels that could distinguish men who did or did not recur. However, there was a distinct signature within the copy number data that predicted differences in time to biochemical relapse, independent of Gleason grade. An important future direction with this signature is to test its prognostic ability within a cohort using lethal prostate cancer as the endpoint.

Cell-cycle progression signature-Rather than a discovery-based approach, Cuzick et $\mathrm{al}^{40}$ used a pathway-based approach, focusing on genes involved in cell cycle progression defined as genes whose expression varied as a function of the cell cycle. Interestingly, genes involved in cell cycle progression have been informative prognostic markers in other cancers including breast ${ }^{45}$. Through curation of the Gene Expression Omnibus database, the researchers identified 126 genes involved in cell cycle regulation. They measured mRNA levels of the genes in a small cohort to examine inter-gene correlations, and further reduced the set to 31 genes based on high correlation to mean expression with the idea that these would provide a robust measure of cell proliferation. In a prostatectomy cohort of 366 prostate cancer patients, mRNA expression of genes in the cell-cycle progression signature predicted biochemical recurrence, independent of Gleason and other clinical factors. Moreover, in a cohort of 337 men with prostate cancer diagnosed on trans-urethral resection of prostate, the signature predicted lethal prostate cancer, independent of Gleason grade and Ki67 expression.

4-marker signature of lethal prostate cancer-Ding et al ${ }^{46}$ used comparative oncogenomics to derive a signature of prostate cancer prognosis. Investigating the noninvasive prostatic intraepithelial neoplasia which develops in Pten-null mice, they found significant upregulation of TGF- $\beta / \mathrm{Smad} 4$ among other pathways. The group then observed that in a mouse engineered to have loss of both Pten and Smad4 within the prostate, metastatic prostate cancer developed. Comparing mRNA expression profiles of tumors from this homogeneous genetic background to the lesions which develop in mice without prostatic Pten, showed alterations in several pathways associated with progression in human tumors. These genes were enlisted into functional assays for proliferation and invasion, and in some cases metastasis. Combining these analyses with the direct targets of Smad4 yielded cyclin D1 and osteopontin as potential prognostic markers. High expression of CCNDI and 
SPPI with loss of SMAD4and PTEN, was investigated as a signature of poor prognosis in prostate cancer. At the mRNA level, the signature was significantly associated with biochemical recurrence and lethal prostate cancer in two small cohorts. Moreover, protein expression of the 4-markers was assessed in a cohort of 367 prostate cancers from men in the Physicians' Health Study who had undergone radical prostatectomy. The 4-marker signature was a significantly better predictor of lethal prostate cancer than Gleason score alone and when combined with age and tumor stage, produced a C-statistic of 0.91 (95\% confidence interval [CI] 0.86-0.96). These 4 markers are currently undergoing independent validation in another large cohort of samples annotated with cancer-specific deaths.

Signature of Gleason score-Given the proven importance of the Gleason score in prediction clinical course, Penney et al ${ }^{47}$ developed a 157 gene mRNA expression signature of associated with Gleason grade. To develop the signature, tumors comprised of Gleason $3+3$ and Gleason $\geq 8$ were compared. When the signature was applied to Gleason 7 tumors, an increased probability of being high grade was associated with a significant increased risk of lethal prostate cancer. For each 33 percent increase in the prediction of high grade tumor, there was an odds ratio of 1.47 (95\% CI 1.11-1.94) for lethal outcome in a multivariate model.

These four signatures hold promise to improve prognostication among men diagnosed with prostate cancer. Important next steps in bringing forward these signatures clinically is the validation in additional cohorts with lethal prostate cancer as the endpoint, determining potential weighting of the individual markers for optimization, as well as the testing of the signatures in biopsy specimens.

\section{b. Circulating biomarkers}

While tumor markers are appealing in that they may represent true biologic changes within the cells of interest, investigators have also explored other sources for prognostic markers in prostate cancer. Blood or urine markers are attractive potential prognostic markers not only for their ease of access but also because they may overcome concerns of the sampling errors and heterogeneity from the tumor itself.

\section{Circulating Tumor Cells}

The development of overt metastases has been typically considered a late event in the malignant progression but there is evolving evidence suggests that dissemination of primary cancer cells to distant sites might occur early in tumorigenesis ${ }^{48}$.

The bone represents the most common location of metastatic disease in prostate cancer and therefore early work on circulating tumor cells focused on tumor cells in the bone marrow. There are significant correlations between the presence of disseminated tumor cells and clinical-pathologic parameters such as high Gleason score or metastatic disease ${ }^{49,50}$. The presence of these cells in the bone marrow at the time of diagnosis is also an independent negative prognostic parameter in patients with localized prostate cancer ${ }^{51}$.

Because bone marrow aspiration is invasive and potentially uncomfortable for the patients, more recent efforts have focused on the detection of circulating tumor cells in the peripheral blood. Using polymerase chain reaction, circulating tumor cells can now be detected in the blood at the time of diagnosis as well as over the course of therapy. Their increased number has been positively associated with higher Gleason score and stage ${ }^{52}$. The detection of PSA mRNA is significantly correlated to time to progression and overall survival ${ }^{53}$. 
Immunologic approaches to detecting circulating tumor cells have subsequently been commercially developed. The Food and Drug Administration has approved a technology (CellSearch, Veridex) that can be used for the monitoring of metastatic breast, colon and prostate cancer. With recently collected peripheral blood, this device is able to isolate single circulating tumor cells by immunomagnetic enrichment followed by fluorimetric count. Data generated using this system shows that circulating tumor cells are detectible in approximately 60 percent of patients with androgen-independent prostate cancer ${ }^{54,55}$. A baseline count of $\geq 5$ cells $/ 7.5 \mathrm{~mL}$ of blood before therapy was found to represent a powerful predictor of poor overall survival ${ }^{56}$. The change in number of detectible circulating tumor cells following therapy is also predictive of clinical outcomes ${ }^{53}$. In one study, patients with a circulating tumor cell count that dropped from $\geq 5$ cells at baseline to $<5$ cells after treatment had a better overall survival compared with those showing an increase during therapy ${ }^{57}$. Though potentially valuable in the metastatic setting, in patients with organ-confined prostate cancer, few circulating tumor cells are detectible using currently available technologies and does not correlate with known prognostic factors ${ }^{58}$.

In addition to their potential prognostic value, there is clearly likely utility in characterizing circulating tumor cells in cancer patients to provide additional information on cancer biology and treatment selection. Newer microfluidic approaches of capturing circulating tumor cells are being commercially developed ${ }^{59,60}$. Both high and low-resolution techniques such as fluorescence in situ hybridization(FISH) and comparative genomic hybridization can be performed on isolated cancer cells to obtain a genomic profile that could be related to prognosis and response to therapy ${ }^{61-63}$. In non-small cell lung cancer, a proof of concept study showed that circulating tumor cells could identify tumors with specific EGFR mutations sensitive to anti-EGFR small molecules demonstrating the value of these "liquid biopsies" 64 .

\section{Urine markers}

Given the proximity of the urethra to the prostate, urine is also considered a potential source of clinically useful biomarkers in men with prostate cancer. The prostate cancer antigen 3 (PCA3) gene is differentially expressed in prostate cancer samples compared to normal prostate tissue ${ }^{65}$. The protein product can be identified in urine, particularly in the first void after a digital rectal exam when tumor cells are known to be present ${ }^{66,67}$. To date, much of the work with PCA3 has been limited to the diagnosis of men with prostate cancer. In this setting, it has been shown that PCA3 can improve upon the specificity of PSA ${ }^{68}$. One study also showed that PCA3 was independently correlated with extracapsular extension identified on radical prostatectomy ${ }^{69}$. The TMPRSS2: ERG fusion has also been investigated in the urine $^{70,71}$. Its presence can be detected in post-digital rectal exam urine and its presence may eventually be used in combination with other biomarkers to improve the specificity of screening for prostate cancer ${ }^{72,73}$. Profiling the metabolites from normal and prostate cancer cells, Sreekumar et al showed that the presence of sarcosine was related to prostate cancer progression and that the level of this metabolite in the urine was associated with the presence of cancer $^{74}$. Whether sarcosine or other metabolites will prove useful as prognostic markers in prostate cancer is yet to be determined.

\section{Serum Markers}

Multiple serum markers other than PSA have been investigated for their potential role in providing prognostic information in prostate cancer. Members of the human kallikrein gene family which include PSA have been investigated with mixed results ${ }^{75,76}$. Given its proven role in the tumor microenvironment TGF- $\beta$ has also been explored in the serum as a prognostic factor ${ }^{77}$. Another marker believed to come from the tumor microenvironment is 
interleukin- 6 and levels of its soluble receptor in the blood have been shown to be prognostic following radical prostatectomy ${ }^{78}$.

\section{Conclusion}

As outlined in this review, molecular markers of prognosis in prostate cancer are plentiful in the literature and to date, have largely focused on individual factors. Despite a wide array of potential markers, they remain to a large extent, unused clinically. This is likely the result of numerous factors including relatively modest effect size for any given marker and poor standardization of the tools of detection and analysis: from antibody selection to biomarker interpretation to selecting cut-points for "positive" and "negative", there is significant room for variability. This variability leads frequently to poor reproducibility between studies and difficulty in interpreting negative results. To improve the interpretability of molecular markers, there are now standardized reporting criteria which are used by some journals for biomarker studies $^{79}$. The wide-spread adoption of these recommendations will help overcome some of these methodological issues. Technologic advances in biomarker assessment such as multispectral imaging ${ }^{80}$ may also prove useful as multiple markers may be needed simultaneously to best predict the clinical course.

More recent studies have focused on the identification and validation of molecular signatures and these appear to hold great promise as prognostic markers in prostate cancer. Approaches looking specifically at Gleason grade ${ }^{47}$ and cell cycle progression ${ }^{40}$ highlight that analyses focused on capturing the biology of prostate cancer may prove very useful in individualizing therapy for men. Further, comparative oncogenomics with functional validation of the drivers of a biologic process ${ }^{46}$ have helped to overcome the significant heterogeneity seen in human prostate cancer to provide critical insights into the prognosis of a man following surgery or possibly at the time of diagnosis. These signatures will need further validation and ultimately trials to foster wide-spread adoption but we appear to be increasingly close to a time when a man can be given a much more reliable prognosis when he is diagnosed with prostate cancer.

\section{References}

1. Johansson JE, Andren O, Andersson SO, et al. Natural history of early, localized prostate cancer. JAMA. 2004; 291:2713-9. [PubMed: 15187052]

2. Holmberg L, Bill-Axelson A, Helgesen F, et al. A randomized trial comparing radical prostatectomy with watchful waiting in early prostate cancer. N Engl J Med. 2002; 347:781-9. [PubMed: 12226148]

3. Bill-Axelson A, Holmberg L, Ruutu M, et al. Radical prostatectomy versus watchful waiting in early prostate cancer. N Engl J Med. 2011; 364:1708-17. [PubMed: 21542742]

4. Shao Y-H, Demissie K, Shih W, et al. Contemporary risk profile of prostate cancer in the United States. J Natl Cancer Inst. 2009; 101:1280-3. [PubMed: 19713548]

5. Siegel R, Ward E, Brawley O, Jemal A. Cancer statistics, 2011: The impact of eliminating socioeconomic and racial disparities on premature cancer deaths. CA Cancer J Clin. 2011; 61:21236. [PubMed: 21685461]

6. Andriole GL, Crawford ED, Grubb RL, et al. Mortality results from a randomized prostate-cancer screening trial. The New England journal of medicine. 2009; 360:1310-9. [PubMed: 19297565]

7. Schroder FH, Hugosson J, Roobol MJ, et al. Screening and prostate-cancer mortality in a randomized European study. N Engl J Med. 2009; 360:1320-8. [PubMed: 19297566]

8. Hugosson J, Carlsson S, Aus G, et al. Mortality results from the Goteborg randomised populationbased prostate-cancer screening trial. Lancet Oncol. 2010; 11:725-32. [PubMed: 20598634]

9. Stephenson AJ, Kattan MW, Eastham JA, et al. Prostate cancer-specific mortality after radical prostatectomy for patients treated in the prostate-specific antigen era. J Clin Oncol. 2009; 27:43005. [PubMed: 19636023] 
10. D'Amico AV, Whittington R, Malkowicz SB, et al. Biochemical outcome after radical prostatectomy, external beam radiation therapy, or interstitial radiation therapy for clinically localized prostate cancer. JAMA. 1998; 280:969-74. [PubMed: 9749478]

11. Kattan MW, Wheeler TM, Scardino PT. Postoperative nomogram for disease recurrence after radical prostatectomy for prostate cancer. J Clin Oncol. 1999; 17:1499-507. [PubMed: 10334537]

12. Kattan MW, Eastham JA, Stapleton AM, Wheeler TM, Scardino PT. A preoperative nomogram for disease recurrence following radical prostatectomy for prostate cancer. J Natl Cancer Inst. 1998; 90:766-71. [PubMed: 9605647]

13. Blute ML, Bergstralh EJ, Iocca A, Scherer B, Zincke H. Use of Gleason score, prostate specific antigen, seminal vesicle and margin status to predict biochemical failure after radical prostatectomy. J Urol. 2001; 165:119-25. [PubMed: 11125379]

14. Partin AW, Piantadosi S, Sanda MG, et al. Selection of men at high risk for disease recurrence for experimental adjuvant therapy following radical prostatectomy. Urology. 1995; 45:831-8. [PubMed: 7538245]

15. Draisma G, Etzioni R, Tsodikov A, et al. Lead time and overdiagnosis in prostate-specific antigen screening: importance of methods and context. J Natl Cancer Inst. 2009; 101:374-83. [PubMed: 19276453]

16. Bianco FJ Jr, Scardino PT, Eastham JA. Radical prostatectomy: long-term cancer control and recovery of sexual and urinary function ("trifecta"). Urology. 2005; 66:83-94. [PubMed: 16194712]

17. D’Amico AV, Moul JW, Carroll PR, Sun L, Lubeck D, Chen MH. Surrogate end point for prostate cancer-specific mortality after radical prostatectomy or radiation therapy. J Natl Cancer Inst. 2003; 95:1376-83. [PubMed: 13130113]

18. Pound CR, Partin AW, Eisenberger MA, Chan DW, Pearson JD, Walsh PC. Natural history of progression after PSA elevation following radical prostatectomy. JAMA. 1999; 281:1591-7. [PubMed: 10235151]

19. Gleason DF, Mellinger GT. Prediction of prognosis for prostatic adenocarcinoma by combined histological grading and clinical staging. J Urol. 1974; 111:58-64. [PubMed: 4813554]

20. Eggener SE, Scardino PT, Walsh PC, et al. Predicting 15-year prostate cancer specific mortality after radical prostatectomy. J Urol. 2011; 185:869-75. [PubMed: 21239008]

21. Albertsen PC, Hanley JA, Barrows GH, et al. Prostate cancer and the Will Rogers phenomenon. J Natl Cancer Inst. 2005; 97:1248-53. [PubMed: 16145045]

22. Stark JR, Perner S, Stampfer MJ, et al. Gleason score and lethal prostate cancer: does $3+4=4+$ 3? J Clin Oncol. 2009; 27:3459-64. [PubMed: 19433685]

23. Andren O, Fall K, Franzen L, Andersson SO, Johansson JE, Rubin MA. How well does the Gleason score predict prostate cancer death? A 20-year followup of a population based cohort in Sweden. J Urol. 2006; 175:1337-40. [PubMed: 16515993]

24. Smith EB, Frierson HF Jr, Mills SE, Boyd JC, Theodorescu D. Gleason scores of prostate biopsy and radical prostatectomy specimens over the past 10 years: is there evidence for systematic upgrading? Cancer. 2002; 94:2282-7. [PubMed: 12001128]

25. Walz J, Chun FK, Klein EA, et al. Nomogram predicting the probability of early recurrence after radical prostatectomy for prostate cancer. J Urol. 2009; 181:601-7. discussion 7-8. [PubMed: 19084864]

26. D'Amico AV, Chen MH, Roehl KA, Catalona WJ. Preoperative PSA velocity and the risk of death from prostate cancer after radical prostatectomy. N Engl J Med. 2004; 351:125-35. [PubMed: 15247353]

27. D'Amico AV, Renshaw AA, Sussman B, Chen M-H. Pretreatment PSA velocity and risk of death from prostate cancer following external beam radiation therapy. JAMA. 2005; 294:440-7. [PubMed: 16046650]

28. Villers A, McNeal JE, Redwine EA, Freiha FS, Stamey TA. The role of perineural space invasion in the local spread of prostatic adenocarcinoma. J Urol. 1989; 142:763-8. [PubMed: 2769857]

29. Nelson CP, Dunn RL, Wei JT, Rubin MA, Montie JE, Sanda MG. Contemporary preoperative parameters predict cancer-free survival after radical prostatectomy: a tool to facilitate treatment decisions. Urol Oncol. 2003; 21:213-8. [PubMed: 12810209] 
30. Pollack A, Hanlon AL, Horwitz EM, Feigenberg SJ, Uzzo RG, Hanks GE. Prostate cancer radiotherapy dose response: an update of the fox chase experience. J Urol. 2004; 171:1132-6. [PubMed: 14767286]

31. Harnden P, Shelley MD, Clements H, et al. The prognostic significance of perineural invasion in prostatic cancer biopsies: a systematic review. Cancer. 2006; 109:13-24. [PubMed: 17123267]

32. Ng JC, Koch MO, Daggy JK, Cheng L. Perineural invasion in radical prostatectomy specimens: lack of prognostic significance. J Urol. 2004; 172:2249-51. [PubMed: 15538241]

33. Boorjian SA, Karnes RJ, Rangel LJ, Bergstralh EJ, Blute ML. Mayo Clinic validation of the D' amico risk group classification for predicting survival following radical prostatectomy. The Journal of urology. 2008; 179:1354-60. discussion 60-1. [PubMed: 18289596]

34. Korets R, Motamedinia P, Yeshchina O, Desai M, McKiernan JM. Accuracy of the Kattan nomogram across prostate cancer risk-groups. BJU Int. 2011; 108:56-60. [PubMed: 21062396]

35. Ludwig JA, Weinstein JN. Biomarkers in cancer staging, prognosis and treatment selection. Nat Rev Cancer. 2005; 5:845-56. [PubMed: 16239904]

36. Kan Z, Jaiswal BS, Stinson J, et al. Diverse somatic mutation patterns and pathway alterations in human cancers. Nature. 2010; 466:869-73. [PubMed: 20668451]

37. Berger MF, Lawrence MS, Demichelis F, et al. The genomic complexity of primary human prostate cancer. Nature. 2011; 470:214-20. [PubMed: 21307934]

38. Hanahan D, Weinberg RA. The hallmarks of cancer. Cell. 2000; 100:57-70. [PubMed: 10647931]

39. Hanahan D, Weinberg RA. Hallmarks of cancer: the next generation. Cell. 2011; 144:646-74. [PubMed: 21376230]

40. Cuzick J, Swanson GP, Fisher G, et al. Prognostic value of an RNA expression signature derived from cell cycle proliferation genes in patients with prostate cancer: a retrospective study. Lancet Oncol. 2011; 12:245-55. [PubMed: 21310658]

41. Artandi SE, DePinho RA. Telomeres and telomerase in cancer. Carcinogenesis. 2010; 31:9-18. [PubMed: 19887512]

42. Concato J, Jain D, Uchio E, Risch H, Li WW, Wells CK. Molecular markers and death from prostate cancer. Ann Intern Med. 2009; 150:595-603. [PubMed: 19414838]

43. Mucci LA, Powolny A, Giovannucci E, et al. Prospective study of prostate tumor angiogenesis and cancer-specific mortality in the health professionals follow-up study. J Clin Oncol. 2009; 27:562733. [PubMed: 19858401]

44. Taylor BS, Schultz N, Hieronymus H, et al. Integrative genomic profiling of human prostate cancer. Cancer Cell. 2010; 18:11-22. [PubMed: 20579941]

45. Mosley JD, Keri RA. Cell cycle correlated genes dictate the prognostic power of breast cancer gene lists. BMC medical genomics. 2008; 1:11. [PubMed: 18439262]

46. Ding Z, Wu CJ, Chu GC, et al. SMAD4-dependent barrier constrains prostate cancer growth and metastatic progression. Nature. 2011; 470:269-73. [PubMed: 21289624]

47. Penney KL, Sinnott JA, Fall K, et al. mRNA Expression Signature of Gleason Grade Predicts Lethal Prostate Cancer. J Clin Oncol. 2011

48. Pantel K, Brakenhoff RH, Brandt B. Detection, clinical relevance and specific biological properties of disseminating tumour cells. Nat Rev Cancer. 2008; 8:329-40. [PubMed: 18404148]

49. Wood DP Jr, Banerjee M. Presence of circulating prostate cells in the bone marrow of patients undergoing radical prostatectomy is predictive of disease-free survival. J Clin Oncol. 1997; 15:3451-7. [PubMed: 9396397]

50. Berg A, Berner A, Lilleby W, et al. Impact of disseminated tumor cells in bone marrow at diagnosis in patients with nonmetastatic prostate cancer treated by definitive radiotherapy. Int $\mathbf{J}$ Cancer. 2007; 120:1603-9. [PubMed: 17230512]

51. Kollermann J, Weikert S, Schostak M, et al. Prognostic significance of disseminated tumor cells in the bone marrow of prostate cancer patients treated with neoadjuvant hormone treatment. J Clin Oncol. 2008; 26:4928-33. [PubMed: 18794550]

52. Kantoff PW, Halabi S, Farmer DA, Hayes DF, Vogelzang NA, Small EJ. Prognostic significance of reverse transcriptase polymerase chain reaction for prostate-specific antigen in men with hormone-refractory prostate cancer. J Clin Oncol. 2001; 19:3025-8. [PubMed: 11408497] 
53. Ross RW, Manola J, Hennessy K, et al. Prognostic significance of baseline reverse transcriptasePCR for prostate-specific antigen in men with hormone-refractory prostate cancer treated with chemotherapy. Clin Cancer Res. 2005; 11:5195-8. [PubMed: 16033836]

54. Danila DC, Heller G, Gignac GA, et al. Circulating tumor cell number and prognosis in progressive castration-resistant prostate cancer. Clin Cancer Res. 2007; 13:7053-8. [PubMed: 18056182]

55. de Bono JS, Scher HI, Montgomery RB, et al. Circulating tumor cells predict survival benefit from treatment in metastatic castration-resistant prostate cancer. Clin Cancer Res. 2008; 14:6302-9. [PubMed: 18829513]

56. Goodman OB Jr, Fink LM, Symanowski JT, et al. Circulating tumor cells in patients with castration-resistant prostate cancer baseline values and correlation with prognostic factors. Cancer Epidemiol Biomarkers Prev. 2009; 18:1904-13. [PubMed: 19505924]

57. Olmos D, Arkenau HT, Ang JE, et al. Circulating tumour cell (CTC) counts as intermediate end points in castration-resistant prostate cancer (CRPC): a single-centre experience. Ann Oncol. 2009; 20:27-33. [PubMed: 18695026]

58. Davis JW, Nakanishi H, Kumar VS, et al. Circulating tumor cells in peripheral blood samples from patients with increased serum prostate specific antigen: initial results in early prostate cancer. $\mathrm{J}$ Urol. 2008; 179:2187-91. discussion 91. [PubMed: 18423725]

59. Stott SL, Lee RJ, Nagrath S, et al. Isolation and characterization of circulating tumor cells from patients with localized and metastatic prostate cancer. Sci Transl Med. 2010; 2:25ra3.

60. Nagrath S, Sequist LV, Maheswaran S, et al. Isolation of rare circulating tumour cells in cancer patients by microchip technology. Nature. 2007; 450:1235-9. [PubMed: 18097410]

61. Attard G, Swennenhuis JF, Olmos D, et al. Characterization of ERG, AR and PTEN gene status in circulating tumor cells from patients with castration-resistant prostate cancer. Cancer Res. 2009; 69:2912-8. [PubMed: 19339269]

62. Leversha MA, Han J, Asgari Z, et al. Fluorescence in situ hybridization analysis of circulating tumor cells in metastatic prostate cancer. Clin Cancer Res. 2009; 15:2091-7. [PubMed: 19276271]

63. Holcomb IN, Grove DI, Kinnunen M, et al. Genomic alterations indicate tumor origin and varied metastatic potential of disseminated cells from prostate cancer patients. Cancer Res. 2008; 68:5599-608. [PubMed: 18632612]

64. Maheswaran S, Sequist LV, Nagrath S, et al. Detection of mutations in EGFR in circulating lungcancer cells. N Engl J Med. 2008; 359:366-77. [PubMed: 18596266]

65. Bussemakers MJ, van Bokhoven A, Verhaegh GW, et al. DD3: a new prostate-specific gene, highly overexpressed in prostate cancer. Cancer Res. 1999; 59:5975-9. [PubMed: 10606244]

66. de Kok JB, Verhaegh GW, Roelofs RW, et al. DD3(PCA3), a very sensitive and specific marker to detect prostate tumors. Cancer Res. 2002; 62:2695-8. [PubMed: 11980670]

67. Landers KA, Burger MJ, Tebay MA, et al. Use of multiple biomarkers for a molecular diagnosis of prostate cancer. Int J Cancer. 2005; 114:950-6. [PubMed: 15609297]

68. Vlaeminck-Guillem V, Ruffion A, Andre J, Devonec M, Paparel P. Urinary prostate cancer 3 test: toward the age of reason? Urology. 2010; 75:447-53. [PubMed: 19586654]

69. Whitman EJ, Groskopf J, Ali A, et al. PCA3 score before radical prostatectomy predicts extracapsular extension and tumor volume. J Urol. 2008; 180:1975-8. discussion 8-9. [PubMed: 18801539]

70. Laxman B, Tomlins SA, Mehra R, et al. Noninvasive detection of TMPRSS2:ERG fusion transcripts in the urine of men with prostate cancer. Neoplasia. 2006; 8:885-8. [PubMed: 17059688]

71. Rostad K, Hellwinkel OJ, Haukaas SA, et al. TMPRSS2:ERG fusion transcripts in urine from prostate cancer patients correlate with a less favorable prognosis. APMIS. 2009; 117:575-82. [PubMed: 19664128]

72. Hessels D, Smit FP, Verhaegh GW, Witjes JA, Cornel EB, Schalken JA. Detection of TMPRSS2ERG fusion transcripts and prostate cancer antigen 3 in urinary sediments may improve diagnosis of prostate cancer. Clin Cancer Res. 2007; 13:5103-8. [PubMed: 17785564]

73. Laxman B, Morris DS, Yu J, et al. A first-generation multiplex biomarker analysis of urine for the early detection of prostate cancer. Cancer Res. 2008; 68:645-9. [PubMed: 18245462] 
74. Sreekumar A, Poisson LM, Rajendiran TM, et al. Metabolomic profiles delineate potential role for sarcosine in prostate cancer progression. Nature. 2009; 457:910-4. [PubMed: 19212411]

75. Haese A, Graefen M, Becker C, et al. The role of human glandular kallikrein 2 for prediction of pathologically organ confined prostate cancer. Prostate. 2003; 54:181-6. [PubMed: 12518322]

76. Karazanashvili G, Abrahamsson PA. Prostate specific antigen and human glandular kallikrein 2 in early detection of prostate cancer. J Urol. 2003; 169:445-57. [PubMed: 12544286]

77. Shariat SF, Shalev M, Menesses-Diaz A, et al. Preoperative plasma levels of transforming growth factor beta(1) (TGF-beta(1)) strongly predict progression in patients undergoing radical prostatectomy. J Clin Oncol. 2001; 19:2856-64. [PubMed: 11387358]

78. Kattan MW, Shariat SF, Andrews B, et al. The addition of interleukin-6 soluble receptor and transforming growth factor beta1 improves a preoperative nomogram for predicting biochemical progression in patients with clinically localized prostate cancer. J Clin Oncol. 2003; 21:3573-9. [PubMed: 12913106]

79. McShane LM, Altman DG, Sauerbrei W, Taube SE, Gion M, Clark GM. Reporting recommendations for tumor marker prognostic studies (REMARK). J Natl Cancer Inst. 2005; 97:1180-4. [PubMed: 16106022]

80. Liu J, Lau SK, Varma VA, et al. Molecular mapping of tumor heterogeneity on clinical tissue specimens with multiplexed quantum dots. ACS Nano. 2010; 4:2755-65. [PubMed: 20377268]

81. Shukla-Dave A, Hricak H, Ishill N, et al. Prediction of prostate cancer recurrence using magnetic resonance imaging and molecular profiles. Clin Cancer Res. 2009; 15:3842-9. [PubMed: 19435838]

82. Taplin ME, Bubley GJ, Shuster TD, et al. Mutation of the androgen-receptor gene in metastatic androgen-independent prostate cancer. N Engl J Med. 1995; 332:1393-8. [PubMed: 7723794]

83. Pollack A, DeSilvio M, Khor LY, et al. Ki-67 staining is a strong predictor of distant metastasis and mortality for men with prostate cancer treated with radiotherapy plus androgen deprivation: Radiation Therapy Oncology Group Trial 92-02. J Clin Oncol. 2004; 22:2133-40. [PubMed: 15169799]

84. Bettencourt MC, Bauer JJ, Sesterhenn IA, Mostofi FK, McLeod DG, Moul JW. Ki-67 expression is a prognostic marker of prostate cancer recurrence after radical prostatectomy. J Urol. 1996; 156:1064-8. [PubMed: 8709308]

85. Demichelis F, Fall K, Perner S, et al. TMPRSS2:ERG gene fusion associated with lethal prostate cancer in a watchful waiting cohort. Oncogene. 2007; 26:4596-9. [PubMed: 17237811]

86. Attard G, Clark J, Ambroisine L, et al. Duplication of the fusion of TMPRSS2 to ERG sequences identifies fatal human prostate cancer. Oncogene. 2008; 27:253-63. [PubMed: 17637754]

87. Gopalan A, Leversha MA, Satagopan JM, et al. TMPRSS2-ERG gene fusion is not associated with outcome in patients treated by prostatectomy. Cancer Res. 2009; 69:1400-6. [PubMed: 19190343]

88. Halvorsen OJ, Haukaas SA, Akslen LA. Combined loss of PTEN and p27 expression is associated with tumor cell proliferation by Ki-67 and increased risk of recurrent disease in localized prostate cancer. Clin Cancer Res. 2003; 9:1474-9. [PubMed: 12684422]

89. McMenamin ME, Soung P, Perera S, Kaplan I, Loda M, Sellers WR. Loss of PTEN expression in paraffin-embedded primary prostate cancer correlates with high Gleason score and advanced stage. Cancer Res. 1999; 59:4291-6. [PubMed: 10485474]

90. Ayala G, Thompson T, Yang G, et al. High levels of phosphorylated form of Akt-1 in prostate cancer and non-neoplastic prostate tissues are strong predictors of biochemical recurrence. Clin Cancer Res. 2004; 10:6572-8. [PubMed: 15475446]

91. Li R, Dai H, Wheeler TM, et al. Prognostic value of Akt-1 in human prostate cancer: a computerized quantitative assessment with quantum dot technology. Clin Cancer Res. 2009; 15:3568-73. [PubMed: 19417030]

92. Schlomm T, Kirstein P, Iwers L, et al. Clinical significance of epidermal growth factor receptor protein overexpression and gene copy number gains in prostate cancer. Clin Cancer Res. 2007; 13:6579-84. [PubMed: 18006757]

93. Moul JW, Friedrichs PA, Lance RS, Theune SM, Chang EH. Infrequent RAS oncogene mutations in human prostate cancer. Prostate. 1992; 20:327-38. [PubMed: 1608859] 
94. Migita T, Ruiz S, Fornari A, et al. Fatty acid synthase: a metabolic enzyme and candidate oncogene in prostate cancer. J Natl Cancer Inst. 2009; 101:519-32. [PubMed: 19318631]

95. Nguyen PL, Ma J, Chavarro JE, et al. Fatty acid synthase polymorphisms, tumor expression, body mass index, prostate cancer risk, and survival. J Clin Oncol. 2010; 28:3958-64. [PubMed: 20679621]

96. Varambally S, Dhanasekaran SM, Zhou M, et al. The polycomb group protein EZH2 is involved in progression of prostate cancer. Nature. 2002; 419:624-9. [PubMed: 12374981]

97. Lee CT, Capodieci P, Osman I, et al. Overexpression of the cyclin-dependent kinase inhibitor p16 is associated with tumor recurrence in human prostate cancer. Clin Cancer Res. 1999; 5:977-83. [PubMed: 10353729]

98. Aaltomaa S, Lipponen P, Eskelinen M, Ala-Opas M, Kosma VM. Prognostic value and expression of p21(waf1/cip1) protein in prostate cancer. Prostate. 1999; 39:8-15. [PubMed: 10221260]

99. Kuczyk M, Machtens S, Hradil K, et al. Predictive value of decreased p27Kip1 protein expression for the recurrence-free and long-term survival of prostate cancer patients. Br J Cancer. 1999; 81:1052-8. [PubMed: 10576664]

100. Yang G, Ayala G, De Marzo A, et al. Elevated Skp2 protein expression in human prostate cancer: association with loss of the cyclin-dependent kinase inhibitor p27 and PTEN and with reduced recurrence-free survival. Clin Cancer Res. 2002; 8:3419-26. [PubMed: 12429629]

101. Sato K, Qian J, Slezak JM, et al. Clinical significance of alterations of chromosome 8 in highgrade, advanced, nonmetastatic prostate carcinoma. J Natl Cancer Inst. 1999; 91:1574-80. [PubMed: 10491435]

102. Prowatke I, Devens F, Benner A, et al. Expression analysis of imbalanced genes in prostate carcinoma using tissue microarrays. Br J Cancer. 2007; 96:82-8. [PubMed: 17146477]

103. Pomerantz MM, Beckwith CA, Regan MM, et al. Evaluation of the 8q24 prostate cancer risk locus and MYC expression. Cancer Res. 2009; 69:5568-74. [PubMed: 19549893]

104. Fordyce CA, Heaphy CM, Joste NE, Smith AY, Hunt WC, Griffith JK. Association between cancer-free survival and telomere DNA content in prostate tumors. J Urol. 2005; 173:610-4. [PubMed: 15643274]

105. Bauer JJ, Sesterhenn IA, Mostofi KF, McLeod DG, Srivastava S, Moul JW. p53 nuclear protein expression is an independent prognostic marker in clinically localized prostate cancer patients undergoing radical prostatectomy. Clin Cancer Res. 1995; 1:1295-300. [PubMed: 9815924]

106. Bauer JJ, Sesterhenn IA, Mostofi FK, McLeod DG, Srivastava S, Moul JW. Elevated levels of apoptosis regulator proteins $\mathrm{p} 53$ and bcl-2 are independent prognostic biomarkers in surgically treated clinically localized prostate cancer. J Urol. 1996; 156:1511-6. [PubMed: 8808919]

107. Scherr DS, Vaughan ED Jr, Wei J, et al. BCL-2 and p53 expression in clinically localized prostate cancer predicts response to external beam radiotherapy. J Urol. 1999; 162:12-6. discussion 6-7. [PubMed: 10379729]

108. Mackey TJ, Borkowski A, Amin P, Jacobs SC, Kyprianou N. bcl-2/bax ratio as a predictive marker for therapeutic response to radiotherapy in patients with prostate cancer. Urology. 1998; 52:1085-90. [PubMed: 9836559]

109. Vergis R, Corbishley CM, Norman AR, et al. Intrinsic markers of tumour hypoxia and angiogenesis in localised prostate cancer and outcome of radical treatment: a retrospective analysis of two randomised radiotherapy trials and one surgical cohort study. Lancet Oncol. 2008; 9:342-51. [PubMed: 18343725]

110. Li R, Younes M, Wheeler TM, et al. Expression of vascular endothelial growth factor receptor-3 (VEGFR-3) in human prostate. Prostate. 2004; 58:193-9. [PubMed: 14716745]

111. Richmond PJ, Karayiannakis AJ, Nagafuchi A, Kaisary AV, Pignatelli M. Aberrant E-cadherin and alpha-catenin expression in prostate cancer: correlation with patient survival. Cancer Res. 1997; 57:3189-93. [PubMed: 9242448]

112. Wikström P, Stattin P, Franck-Lissbrant I, Damber JE, Bergh A. Transforming growth factor beta1 is associated with angiogenesis, metastasis, and poor clinical outcome in prostate cancer. Prostate. 1998; 37:19-29. [PubMed: 9721065] 


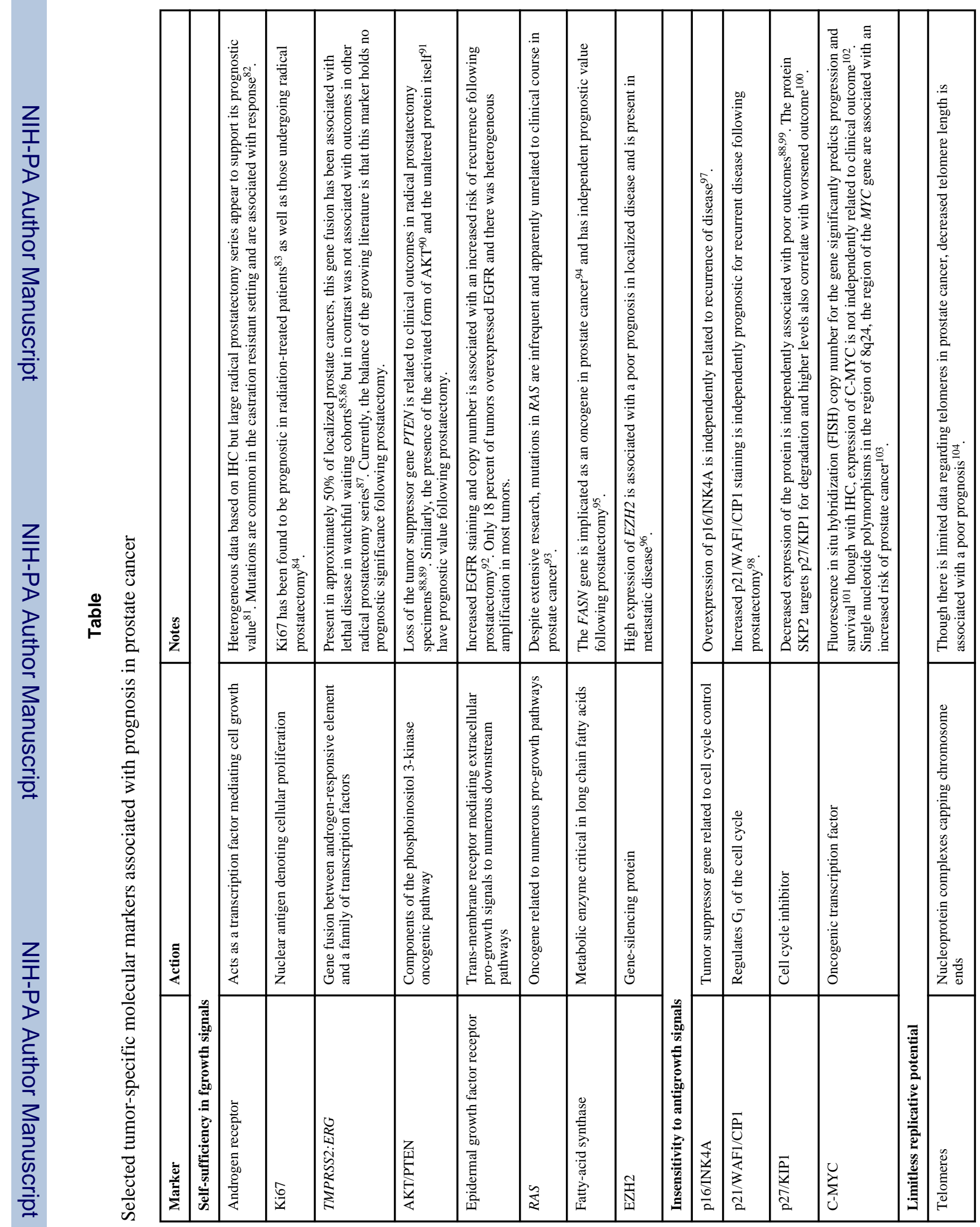

Cancer J. Author manuscript; available in PMC 2012 November 1. 


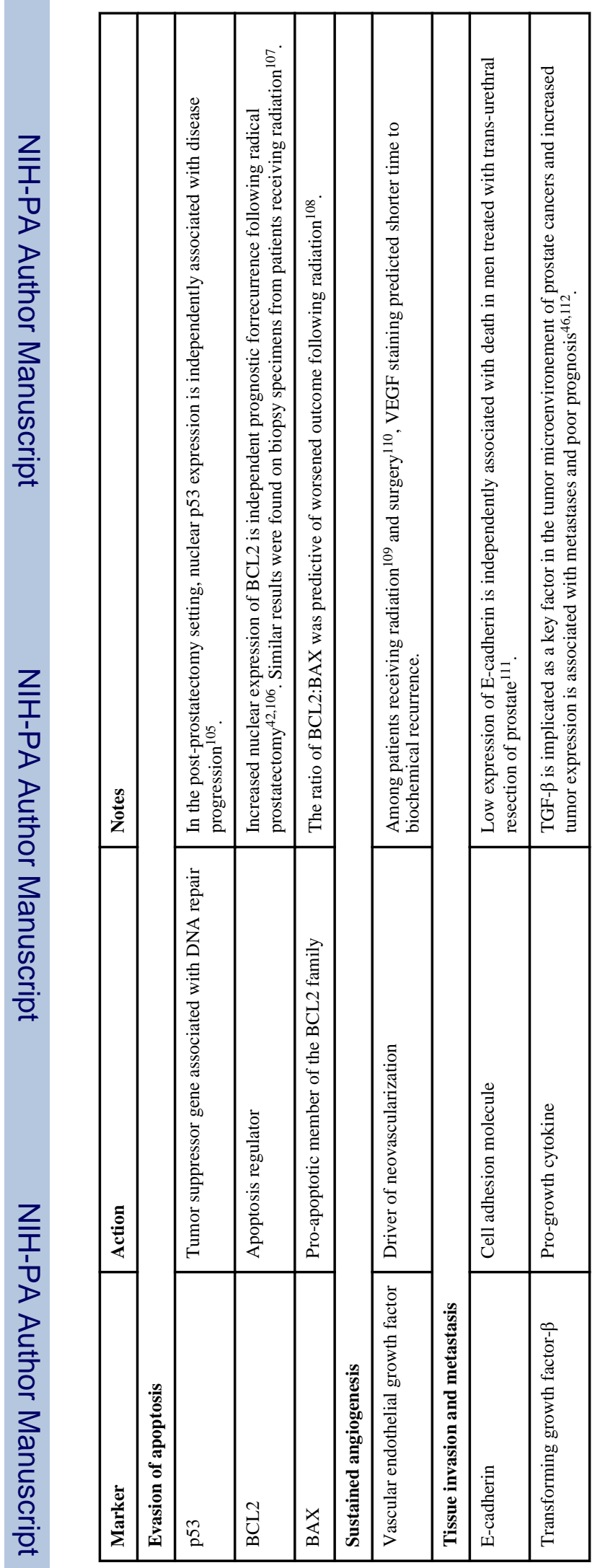

Cancer J. Author manuscript; available in PMC 2012 November 1. 